\title{
Cow and camel milk-derived whey and casein protein hydrolysates demonstrated effective antifungal properties against selected Candida species
}

\author{
Priti Mudgil, ${ }^{1}$ May AlMazroui, ${ }^{1}$ Ali Ali Redha, ${ }^{2}$ Bhanu Priya Kilari, ${ }^{1}$ Shabarinath Srikumar, ${ }^{1}$ \\ and Sajid Maqsood ${ }^{1,3 *}$ \\ ${ }^{1}$ Department of Food Science, College of Agriculture and Veterinary Medicine, United Arab Emirates University, Al Ain, 15551, \\ United Arab Emirates \\ ${ }^{2}$ Chemistry Department, School of Science, Loughborough University, Loughborough LE11 3TU, United Kingdom \\ ${ }^{3}$ Zayed Centre of Health Sciences, United Arab Emirates University, Al Ain, 15551, United Arab Emirates
}

\begin{abstract}
Bioactive peptides derived from milk proteins are widely known to possess antibacterial activities. Even though the antibacterial effects of milk-derived peptides are widely characterized, not much focus is given to their antifungal characterization. Therefore, in this study, we investigated the antifungal properties of camel and cow whey and casein hydrolysates against various species of pathogenic Candida. The hydrolysates were produced using 2 enzymes (alcalase and protease) at differing hydrolysis durations $(2,4$, and $6 \mathrm{~h}$ ) and tested for their antifungal properties. The results showed that intact cow whey and casein proteins did not display any anti-Candida albicans properties, whereas the alcalase-derived $2 \mathrm{~h}$ camel casein hydrolysate (CA-CA2) displayed a higher percentage of inhibition against Candida albicans $(93.69 \pm 0.26 \%)$ followed by the cow casein hydrolysate generated by protease- $6 \mathrm{~h}$ (Co-C-P6; $81.66 \pm 0.99 \%)$, which were significantly higher than that of fluconazole, a conventional antifungal agent $(76.92 \pm 4.72 \%)$. Interestingly, when tested again Candida krusei, camel casein alcalase 2 and $4 \mathrm{~h}$ (CA-C-A2 and CA-C-A4), and cow whey alcalase-6 h (CO-W-A6) hydrolysates showed higher antifungal potency than fluconazole. However, for Candida parapsilosis only camel casein alcalase-4 h (Ca-C-A4) and cow casein protease-6 $\mathrm{h}$ (Co-C-P6) hydrolysates were able to inhibit the growth of $C$. parapsilosis by $19.31 \pm 0.84 \%$ and $23.82 \pm$ $4.14 \%$, respectively, which was lower than that shown by fluconazole $(29.86 \pm 1.11 \%)$. Overall, hydrolysis of milk proteins from both cow and camel enhanced their antifungal properties. Camel milk protein hydrolysates
\end{abstract}

Received June 30, 2021.

Accepted October 26, 2021

*Corresponding author: Sajid.m@uaeu.ac.ae were more potent in inhibiting pathogenic Candida species as compared with cow milk protein hydrolysates. This is the first study that highlights the antifungal properties of camel milk protein hydrolysates.

Key words: camel milk hydrolysates, cow milk hydrolysates, antifungal activity, Candida, bioactive peptides

\section{INTRODUCTION}

Fungal infections are a major problem for immunocompromised patients. Candida albicans is the most infective among 17 Candida species that can cause human infections (Dadar et al., 2018). Candida albicans, a commensal fungus usually observed infecting the human oral cavity and gastrointestinal tract, is also one of the main causes of mucosal and systemic infections (Mayer et al., 2013; Nobile and Johnson, 2015). These fungal infections are linked with high mortality rates specifically among people with compromised immune systems (Li et al., 2016). Current therapeutic approaches have toxic side effects and the development of drug-resistant strains has resulted in a surge of Candida-associated mortality. Therefore, the development of parallel antifungal therapeutic strategies for candidiasis patients, especially, is very important (de Oliveira Santos et al., 2018).

In addition to Candida albicans, Candida krusei and Candida parapsilosis are also considered to be 2 common pathogenic species of Candida (Turner and Butler, 2014). Candida kruse $i$ is an emerging fungal nosocomial pathogen affecting the immunocompromised, as well as those with hematological malignancies (Jamiu et al., 2021). It has inherent resistance to antifungal drugs such as fluconazole. Candida parapsilosis is the most common cause of hospital-related bloodstream infections and is commonly found on the skin, hands, and mucous membranes of healthy people (Trofa et al., 
2008). It has also become a significant cause of serious, drug-resistant, nosocomial infections and is a nonobligate human pathogen (Trofa et al., 2008).

One of the proposed therapeutic antifungal strategies is antimicrobial peptides (Chen and Lu, 2020). Antimicrobial peptides (AMP), currently widely researched, can prevent the growth or inhibit microorganisms through multiple mechanisms including altering bacterial membrane activity, interfering with metabolic pathways, or interacting with cytoplasmic components (Esmaeilpour et al., 2016). Milk, irrespective of its origin, is a rich source of AMP (Mohanty et al., 2016).

Camel milk is predominantly produced in Southeast Asian as well as Middle Eastern and North African countries and is rich in minerals, vitamins, and fat. The physicochemical composition of camel milk is known to be different than that of milk from other domesticated dairy animals. Overall, camel milk is known to possess lesser fats, proteins, and carbohydrates, but higher water, vitamins, minerals, and antimicrobial factors (Abdalla et al., 2015; Khalesi et al., 2017). The casein constituent present in camel milk is divided into 4 fractions, $\alpha_{S^{1}}$-casein, $\alpha_{S^{2}}$-casein, $\beta$-casein, and $\kappa$-casein, with mean concentrations of $2.4-10.3,0.3-3.9,5.5-29.0$, and $0.1-2.4 \mathrm{~g} / \mathrm{L}$, respectively. The ratio of $\alpha_{\mathrm{S}_{1}} \mathrm{CN}$, $\alpha_{\mathrm{S}_{2}} \mathrm{CN}, \beta-\mathrm{CN}$, and $\kappa-\mathrm{CN}$ in camel milk is reported as 26:4:67:3 (wt/wt) in comparison to 38:10:36:12 (wt/ wt) in bovine milk (Swelum et al., 2021). Another main component of camel milk protein is whey protein, which constitutes around $25 \%$ of total proteins (i.e., around 0.6-0.8\%; Farag and Kebary, 1992; Mehaia et al., 1995; Khaskheli et al., 2005). Unlike bovine milk where $\beta$-LG $(52.6 \%)$ comprise the main whey protein followed by $\alpha$-LA $(26.0 \%)$, camel milk is rich in $\alpha$-LA $(0.3-2.9 \mathrm{~g} / \mathrm{L}$; $50 \%$ ) followed by serum (35\%) and is devoid of $\beta$-LG, similar to human milk and indicating its resemblance to human milk (El-Agamy, 2009; Omar et al., 2016). Moreover, $\beta$-LG is the main protein responsible for triggering bovine milk allergies; therefore, lacking $\beta$-LG gives camel milk its antiallergic effects. Additionally, camel milk is reportedly 3 to 4 times richer in lactoferrin and immunoglobulins $(0.2-1.0 \mathrm{~g} / \mathrm{L})$, major antimicrobial whey proteins, than its bovine counterpart (100-120 $\mathrm{mg} / \mathrm{L}$ ), suggesting a definite role in conferring higher antimicrobial properties to the camel milk (Konuspayeva et al., 2007). The rich composition of camel milk primarily defines its bioactive properties, protection against heavy metal toxicity, and antimicrobial activity (Ahamad et al., 2017). Camel milk shows antimicrobial activity against a variety of pathogens and the rich content of AMP could underpin its antimicrobial activities (Alavi et al., 2017). Moreover, caseins of camel milk are also known to be more sensitive to proteolysis than cow milk caseins (Tagliazucchi et al., 2018; Mudgil et al., 2022). Overall, primarily due to the differences between protein content, composition, and structures, the biological as well as technological properties of camel and cow milk are expected to be different. The bioactivities and functional properties of camel milk proteins can further be enhanced by hydrolyzing the proteins to form shorter bioactive peptides using different enzymes such as trypsin, pepsin, $\alpha$-chymotrypsin, papain, and alcalase (Al-Shamsi et al., 2018). These protein hydrolysates are pharmaceutically pertinent, owing to their potential in preventing and treating several diseases including fungal infections (Alavi et al., 2017; Ishak and Sarbon, 2018). Though the antibacterial properties of camel milk protein hydrolysates are widely characterized, their antifungal properties are not, barring very few investigations (Algboory et al., 2017). Therefore, this study was aimed to close this research gap by carrying out a comparative analysis of the antifungal properties of camel and cow milk protein hydrolysates produced from their casein and whey protein fractions using proteolytic endopeptidase enzymes such as alcalase and protease from Streptomyces griseus. Both the enzymes used for hydrolysis were selected after a thorough review of literature pertaining to their high specificity toward milk proteins, and long history of their application for production of antimicrobial bioactive peptides from food proteins (Kumar et al., 2016a; Osman et al., 2016). Alcalase, a serine protease, is reported to act specifically upon caseins much more efficiently than any other food grade enzyme (Jung et al., 2016), whereas protease from Streptomyces griseus is a mixture of many proteases (including 5 serine-type proteases, $2 \mathrm{Zn}^{2+}$ endopeptidases, $2 \mathrm{Zn}^{2+}$ leucine aminopeptidases, and $1 \mathrm{Zn}^{2+}$ carboxypeptidase), theoretically providing it a broad range of specificity toward protein cleavage that could yield a mixture of all possible fragments.

\section{MATERIALS AND METHODS}

\section{Materials}

Enzymes used included alcalase (from Bacillus licheniformis; $\geq 2.4 \mathrm{U} / \mathrm{g}$ ) and protease (from Streptomyces griseus; $\geq 3.5$ units/mg of solids) procured from Sigma-Aldrich. The commercial drug fluconazole was obtained from Pfizer. Three Candida strains used, Candida albicans (ATCC 90028), Candida krusei (ATCC 6258), and Candida parapsilosis (ATCC 22019), were kindly provided by Khaled Tarabeily, Department of Biology, College of Science, United Arab Emirates University, United Arab Emirates. 


\section{Separation of Casein and Whey Protein Fractions from Camel and Cow Milk}

Raw camel (Camelus dromedaries) and cow (Bos taurus: Holstein Friesian) milk were obtained from different healthy camels and cows of the same breed present in a local farm in Al Ain, United Arab Emirates. Milk samples were skimmed by centrifugation at $2,326 \times g$ for $20 \mathrm{~min}$ at $10^{\circ} \mathrm{C}$ (Allegra X-30R, Beckman Coulter Inc.). Camel and cow milk caseins and whey were separated by isoelectric precipitation of proteins through adjustment of $\mathrm{pH}$ at 4.0 using $1 \mathrm{M} \mathrm{HCl}$. The curd obtained was allowed to settle for $1 \mathrm{~h}$ at $4^{\circ} \mathrm{C}$ and separation of casein (as a pellet) and whey fraction (supernatant) was performed at 10,000 $\times g, 15 \mathrm{~min}$ at $4^{\circ} \mathrm{C}$. For the separation of caseins and whey proteins from camel milk, a slightly modified method described by Baba et al. (2021) and Mudgil et al. (2021) was followed. Both fractions (casein and whey) thus obtained were frozen at $-20^{\circ} \mathrm{C}$ and freeze-dried (temperature $=$ $-80^{\circ} \mathrm{C}$, pressure $=0.1$ bar) using a Telstar freeze-drier (Telstar), and finally stored at $-20^{\circ} \mathrm{C}$ until further utilization.

\section{Preparation of Camel and Cow Milk Protein Hydrolysates}

For the preparation of hydrolysates, camel and cow protein fractions (casein and whey) were completely dissolved in deionized water to achieve $3 \%$ protein content and $\mathrm{pH}$ was adjusted to 8.0 using $1 \mathrm{M} \mathrm{NaOH}$. The protein solutions were then divided into 3 different batches (50 mL each replicate), where one batch was kept as unhydrolyzed control and the other 2 batches were subjected to protein hydrolysis using alcalase and protease at $50^{\circ} \mathrm{C}$, respectively, under constant stirring in a water bath with an enzyme-to-substrate (protein) ratio of 1:100 (wt/wt) for up to $6 \mathrm{~h}$ under $\mathrm{pH}$-controlled conditions. Hydrolysate samples were taken every $2 \mathrm{~h}$ to obtain 3 hydrolysate samples of different hydrolysis duration for each set (Kamal et al., 2021). After collection of each sample, the enzyme was inactivated by boiling in a water bath for 10 min to deactivate the enzyme. The unhydrolyzed controls were also treated to the same temperature of incubation for $6 \mathrm{~h}$ and boiled at the end of incubation. All of the samples obtained, including unhydrolyzed controls and hydrolysate samples, were subjected to centrifugation at $10,000 \times g$ for 10 min at $4^{\circ} \mathrm{C}$, and supernatant was collected (Mudgil et al., 2020). Thereafter, all samples thus obtained were filter sterilized using $0.45-\mu \mathrm{m}$ syringe filters and stored at $-20^{\circ} \mathrm{C}$ until further analysis. For all of the hydrolysates, 3 batches were produced, which served as triplicates.

\section{Degree of Hydrolysis}

The degree of hydrolysis (DH) was determined using the o-phthaldialdehyde (OPA) method based on the original method of Nielsen et al. (2001) as further described by (Mudgil et al., 2019). The OPA reagent was prepared fresh by combining $25 \mathrm{~mL}$ of sodium tetraborate buffer (100 mM; pH 9.3), $2.5 \mathrm{~mL}$ of SDS (20\%, wt/wt), $40 \mathrm{mg}$ of OPA (dissolved in $1 \mathrm{~mL}$ of methanol), and $100 \mu \mathrm{L}$ of $\beta$-mercaptoethanol and diluted to $50 \mathrm{~mL}$ with deionized water (Elix-10, Millipore). Briefly, 20 $\mu \mathrm{L}$ of the control and samples was seeded to 96-well microplates and mixed with $200 \mu \mathrm{L}$ of OPA reagent. The absorbance (Abs) was measured at $340 \mathrm{~nm}$ using the Epoch 2 Microplate Spectrophotometer (BioTek Instruments). Degree of hydrolysis was calculated using the following equation:

$\mathrm{DH} \%=$

Abs of hydrolyzed proteins - Abs of unhydrolyzed proteins Abs of unhydrolyzed casein $\times 100$.

\section{Antifungal Activity of Hydrolysates Against Various Candida Species Via Optical Density Method}

Candida albicans ATCC 90028, Candida krusei ATCC 6258, and Candida parapsilosis ATCC 22019 were cultured overnight in Wickerham broth. Wickerham media was prepared fresh using glucose $(10.0 \mathrm{~g})$, peptone (5.0 $\mathrm{g})$, malt extract $(3.0 \mathrm{~g})$, yeast extract $(3.0 \mathrm{~g})$, diphenyl amine $(0.5 \mathrm{~g})$, agar $(20.0 \mathrm{~g})$, and distilled water $(1 \mathrm{~L})$. Cultures were diluted to give an approximate count of $1 \times 10^{4} \mathrm{cfu} / \mathrm{mL}$. This suspension $(50 \mu \mathrm{L})$ was then mixed with $50 \mu \mathrm{L}$ of protein hydrolysates $(1.5 \mathrm{mg}$ protein equivalent) and $200 \mu \mathrm{L}$ of Wickerham broth into sterile round-bottom 96-well polystyrene microtiter plates (Sarstedt) and the kinetic analysis of Candida growth was measured at $600 \mathrm{~nm}$ in a microplate reader (Epoch 2, BioTek Instruments) maintained at $37^{\circ} \mathrm{C}$ for $18 \mathrm{~h}$ with samples being monitored after every $2 \mathrm{~h}$. At the end of the incubation period, the line graphs were interpolated from the data obtained.

\section{Antifungal Activity of the Selected Hydrolysates Using Viable Cell Count}

The 4 hydrolysates (Co-W-A6, Co-C-P6, Ca-C-A2, $\mathrm{Ca}-\mathrm{C}-\mathrm{A} 4)$ were further selected to investigate their antifungal activity based on the log cfu count method. Co-W-P6, Ca-C-A2, and Ca-C-A4 were specifically selected for their potential inhibition against fluconazoleresistant Candida strains (i.e., C. krusei and C. parapsilopsis). Similarly, Co-C-P6 was selected for its highest 
inhibition against C. krusei, which was monitored in the antifungal study using the optical density (OD) method and represented as a color-coded figure in Supplemental Figure S1 (https://data.mendeley.com/ datasets/jgsz943d2v/1). Unhydrolyzed cow casein and cow whey samples $(30 \mathrm{mg} / \mathrm{mL}$ protein equivalent) as negative controls (weakest activity) and an antifungal agent fluconazole $(1 \mathrm{mg} / \mathrm{mL}$ in sterile water $)$ as a positive control were also selected for their effect on the $\log$ cfu count against C. albicans, C. krusei, and C. parapsilopsis and the percentages of inhibition were determined. For this, overnight grown cultures of all 3 Candida were diluted to an OD of 0.05 and grown to an OD of 0.4 in Wickerham broth following the protocol described by Rossignol et al. (2011). The cells were then treated with the selected hydrolysates for $6 \mathrm{~h}$. Cells were sampled, and aliquots were prepared by dilution in sterile peptone water, plated on yeast extract peptone dextrose agar plates, and incubated at $37^{\circ} \mathrm{C}$ for $24 \mathrm{~h}$ for cfu counting. Colony counts were performed, and percent inhibition was calculated as

$\%$ Inhibition $=\left[1-\left(\frac{\mathrm{cfu} \text { of hydrolysate-treated cells }}{\mathrm{cfu} \text { of untreated samples }}\right)\right] \times 100$.

\section{Statistical Analysis}

Hydrolysates were generated in 3 different batches which represented 3 replicates. The data were analyzed statistically (significance at $P<0.05$ ) using ANOVA and appropriate means separation was conducted using Tukey's multiple range test using SPSS statistical software package (SPSS 25.0 for Windows, IBM Corp.).

\section{RESULTS AND DISCUSSION}

\section{Degree of Hydrolysis}

The DH for each hydrolysate produced with each enzyme and hydrolysis time was determined by measuring the soluble peptide released during hydrolysis, and the results reported as percentages are shown in Figure $1(\mathrm{~A}-\mathrm{D})$. It was noted that, for both casein and whey proteins, there was a significant increase $(P<$ 0.05 ) in the $\mathrm{DH}$ with the increase in the duration of hydrolysis $(2-6 \mathrm{~h})$ using alcalase and protease enzymes [Figure $1(\mathrm{~A}-\mathrm{D})$ ]. The highest hydrolysis, however, was achieved by the action of protease on camel casein (CaC-P6, 97.7\%; Figure 1A). Consequently, the DH for both camel and cow milk proteins (casein and whey) at the longest hydrolysis duration $(6 \mathrm{~h})$ was found to be higher in samples hydrolyzed by protease compared with alcalase $(P<0.05)$. For example, the $\mathrm{DH}$ of camel whey protease-generated hydrolysates were $47.9 \%$,
$78.7 \%$, and $90.5 \%$ for Ca-W-P2, Ca-W-P4, and Ca-W$\mathrm{P} 6$, respectively, whereas for alcalase-derived hydrolysates, the $\mathrm{DH}$ values were $24.09 \%, 53.77 \%$, and $73.56 \%$ for Ca-W-A2, Ca-W-A4, and Ca-W-A6, respectively (Figure 1B).

The cow whey protein hydrolysates also showed a similar trend where the protease appeared to have a significant and effective effect on the $\mathrm{DH}$, resulting in a DH of $23.4 \%, 82.3 \%$, and $96.7 \%$, respectively, after 2,4 , and $6 \mathrm{~h}$ of hydrolysis (Co-W-P2, Co-W-P4, and Co-W-P6), whereas for alcalase the $\mathrm{DH}$ values were $18.65 \%, 61.54 \%$, and $70.79 \%$ for Co-W-A2, Co-W-A4, and $\mathrm{Co}-\mathrm{W}-\mathrm{A} 6$, respectively (Figure 1D). Reflecting a similar trend, the DH of cow casein protease hydrolysates increased with the increase in the time of hydrolysis from 2 to $6 \mathrm{~h}$, resulting in a $\mathrm{DH}$ of $26.2 \%, 82.6 \%$, and $93.4 \%$ for Co-C-P2, Co-C-P4, and Co-C-P6, respectively (Figure 1C), whereas for alcalase-generated hydrolysates the $\mathrm{DH}$ values were $23.55 \%, 41.06 \%$, and $60.80 \%$ for Co-C-A2, Co-C-A4, and Co-C-A6, respectively. Similarly, for camel casein hydrolysates obtained via protease and alcalase hydrolysis, $\mathrm{DH}$ values were observed to be $38.22 \%, 49.08 \%, 83.47 \%$ and $42.03 \%$, $70.77 \%, 97.79 \%$ for Ca-C-A2, Ca-C-A4, Ca-C-A6 and Ca-C-P2, Ca-C-P4, and Ca-C-P6, respectively. All of the above values acquired for protease hydrolysates indicate that protease is more effective in hydrolyzing milk proteins compared with alcalase. The differences observed DH values of camel and cow protein could be due to the difference in specificity toward milk protein sequences. Alcalase is known to cleave peptide bonds on the carboxyl side of Glu, Met, Leu, Tyr, Lys, and Gln. Moreover, alcalase preferentially cleaves at cleavage sites where Glu is in the $\mathrm{P} 1$ position and a hydrophobic residue is in either at $\mathrm{P} 2^{\prime}$ or $\mathrm{P} 3^{\prime}$ positions. Whereas, as indicated previously, protease from Streptomyces griseus, a mixture of many proteases, cleaves peptide bonds from both the N- and C-terminus and within the peptide with a broad range of specificity yields peptide fragments of all possibilities. In addition, protease is known for its greater activation by calcium ions, which are abundant in milk, leading to higher proteolytic activity that produces a wide range of peptide fragments (Spungin and Blumberg, 1989).

We confirm previous studies which showed the advantage of protease hydrolysis over bromelain, papain, and trypsin in hydrolyzing proteins (Shu et al., 2018). The report also emphasized protease's broad specificity as alkaline protease was found to cause increased DH in goat milk compared with papain, trypsin, and bromelain, suggesting more binding sites compared with other enzymatic reactions (Shu et al., 2018). Our results also confirmed previous studies where camel milk proteins were shown to have higher DH with increased time in- 
A

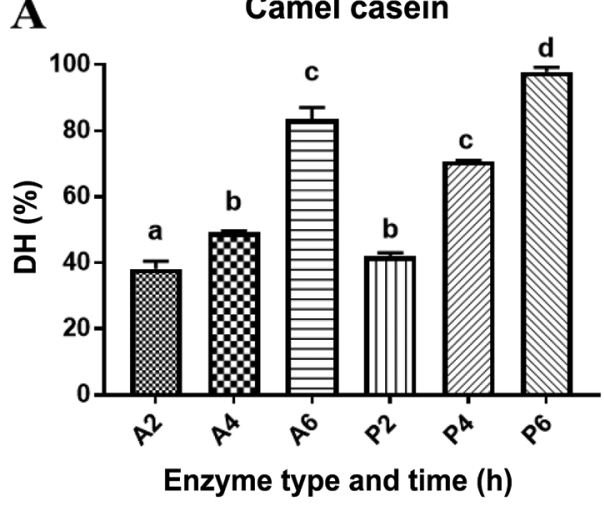

C

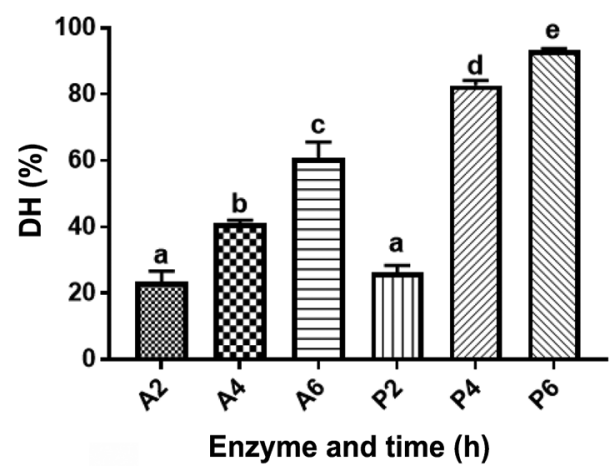

B

Camel whey

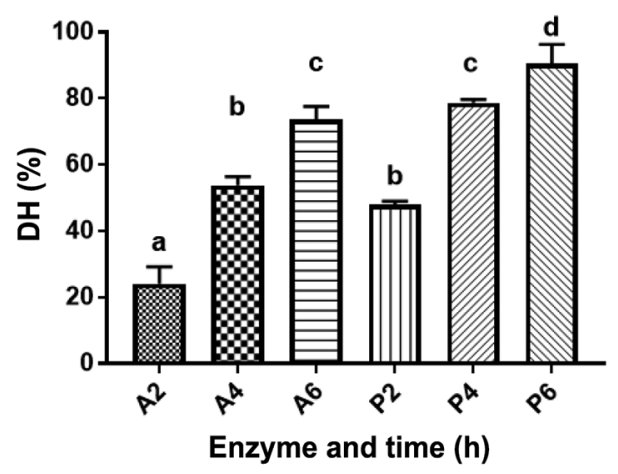

D
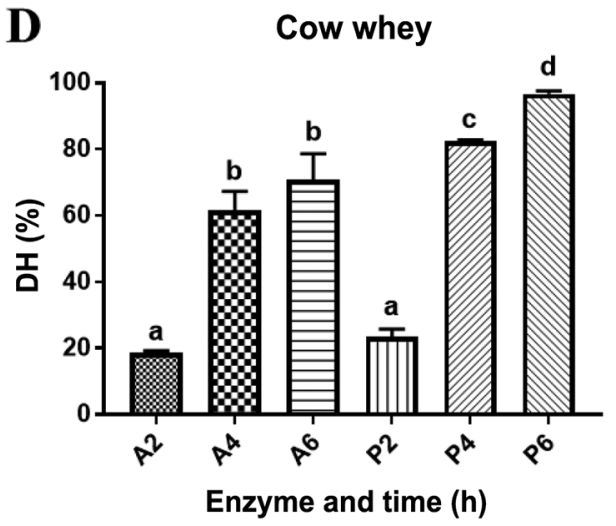

Figure 1. Degree of hydrolysis (DH) of protein hydrolysates derived from camel milk casein (A) and whey (B) and cow milk casein (C) and whey (D) obtained by alcalase and protease hydrolysis at an enzyme-to-substrate ratio of $1: 100 \mathrm{wt} / \mathrm{wt}$ after 2,4 , and $6 \mathrm{~h}$ of hydrolysis at $50^{\circ} \mathrm{C}$. A2, A4, and A6 refer to alcalase-derived hydrolysates; P2, P4, and P6 refer to protease-derived hydrolysates at 2, 4, and 6 h of hydrolysis, respectively. All values are expressed as mean $\pm \mathrm{SD}(\mathrm{n}=3)$. Different letters indicate a significant difference among different hydrolysates $(P<0.05)$.

cubations than other milk proteins. A recent study indicated higher susceptibility of camel and cow casein to protease hydrolysis in comparison to alcalase hydrolysis (Mudgil et al., 2021, 2022). Similarly, Abderrahmane et al. (2015) reported that $\mathrm{DH}$ of camel whey proteins hydrolyzed by pepsin showed greater hydrolysis (31.6\%) than the cow whey proteins $(21.3 \%)$. Likewise, camel and cow $\alpha$-LA hydrolyzed by trypsin and chymotrypsin displayed higher DH compared with cow $\alpha$-lactoferrin (Salami et al., 2009). Similarly, our results also verify earlier results where the DH for the camel caseins increased considerably with the higher incubation time (Kumar et al., 2016b; Mudgil et al., 2019). Yet, the reported DH of milk proteins varies in different studies primarily due to the differences in enzyme-to-substrate ratio, type of protein, and sequence of the protein involved (Bahari et al., 2020). Factors such as the type of the enzyme, the concentration of enzyme and substrate, incubation time, $\mathrm{pH}$, and temperature are also known to affect the final DH (Shahi et al., 2020). Alcalase is a serine protease and, therefore, to generate different and unique peptides, different enzymes having different specificity were selected. Overall, the results of our current study were consistent with several studies which reported that differences in the type of enzyme used for hydrolysis will affect the DH (Sbroggio et al., 2016; Bao et al., 2017; Shahi et al., 2020).

\section{Inhibition Activity of Hydrolysates Against Various Candida Species Using OD Method}

The inhibitory activity of camel and cow casein and whey proteins and their alcalase and protease-derived hydrolysates against $C$. albicans, $C$. krusei, and $C$. parapsilopsis were investigated using the OD method at $600 \mathrm{mn}$. Results obtained related to the effect of hydrolysates against $C$. albicans after $18 \mathrm{~h}$ in terms of gain in OD from the initial OD at $0 \mathrm{~h}$ indicated that among all of the hydrolysates camel whey hydrolysate produced through $6 \mathrm{~h}$ of protease hydrolysis (Ca-WP6) produced maximum arrest of $C$. albicans growth, followed by cow casein hydrolysates (Co-C-P6) and camel casein hydrolysates, prepared using alcalase with a hydrolysis duration of $6 \mathrm{~h}$ (Ca-C-A6; Figure 2A-D). 
Overall, cow casein hydrolysates, prepared using alcalase with a hydrolysis duration of $2 \mathrm{~h}$ (Co-C-A2), cow whey hydrolysates, prepared using alcalase after $4 \mathrm{~h}$, and cow whey hydrolysates, prepared using protease with a hydrolysis duration of $4 \mathrm{~h}$, were found among the hydrolysates with the weakest activity against $C$. albicans. Among camel protein hydrolysates Ca-W-P2 and $\mathrm{Ca}-\mathrm{C}-\mathrm{P} 4$ were deciphered to be the weakest hydrolysates against $C$. albicans (Supplemental Figure S1). The heat map shown in Supplemental Figure S1 also indicated similar antifungal activity against $C$. albicans among Co-C-P6 and Ca-C-P6 hydrolysate (Supplemental Figure S1). In general, camel protein hydrolysates showed higher antifungal activity in comparison with cow protein hydrolysates against $C$. albicans.

As per the results obtained against $C$. krusei (Figure $3 \mathrm{~A}-\mathrm{D}$ ), overall, cow whey hydrolysates produced using protease after $4 \mathrm{~h}$ of hydrolysis (Co-W-P4), followed by Co-C-P6 and Co-C-P2, displayed maximum suppression of C. krusei growth. Among camel protein hydrolysates alcalase-generated hydrolysates after $4 \mathrm{~h}$ of hydrolysis (i.e., Ca-W-A4 and Ca-C-A4 displayed higher antifungal activity against C. krusei). Interestingly, intact camel whey was found to be a potent inhibitor of C. krusei growth and it was suggested that enzymatic hydrolysis somehow led to a decline in its antifungal activity against $C$. krusei. On the contrary, intact cow casein protein supported the growth of $C$. krusei even better than normal growth media and could be attributed to the ability of $C$. krusei to utilize cow casein as a source of nutrition more efficiently (Figure 3D). Similar results were also seen for hydrolysates prepared using camel whey (i.e., Ca-W-A4, Ca-W-P4, and Ca-W-P6; Figure $3 \mathrm{~A}$ and $\mathrm{C}$ ).

The third Candida species tested in this study was C. parapsilopsis. Among all of the samples tested, it was observed that alcalase-generated cow and camel protein hydrolysates in general displayed higher inhibition of $C$. parapsilopsis growth than protease-generated hydrolysates. Overall, cow whey hydrolysate (Co-WA6) showed the highest antifungal activity (Figure 4B). Among the camel protein hydrolysates, the hydrolysates prepared using alcalase with a hydrolysis duration of $4 \mathrm{~h}$ for both whey and casein (Ca-W-A4 and
A

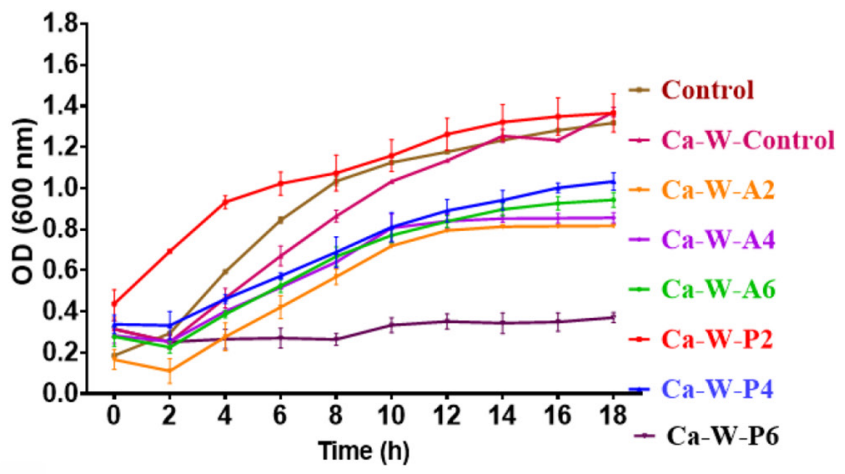

C

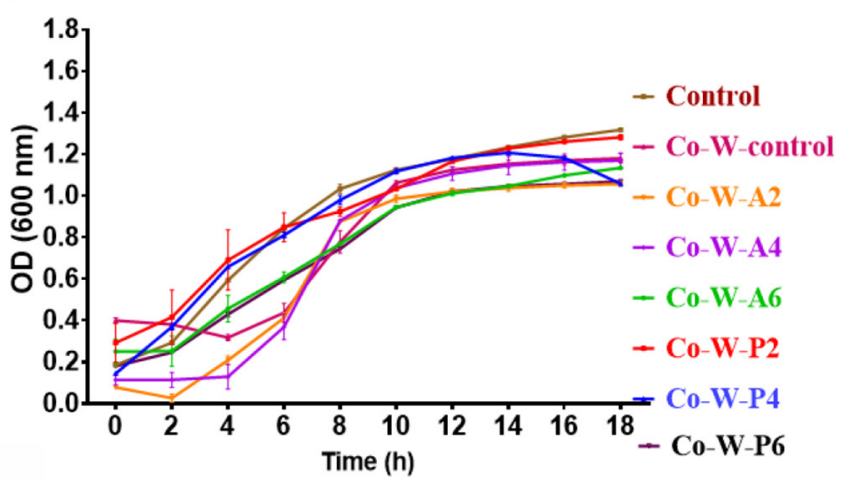

B Camel casein (CaC)

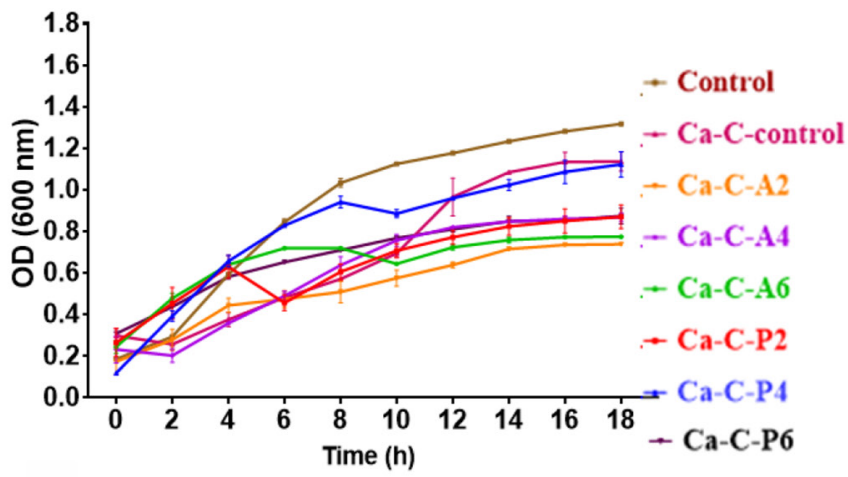

D Cow Casein (CoC)

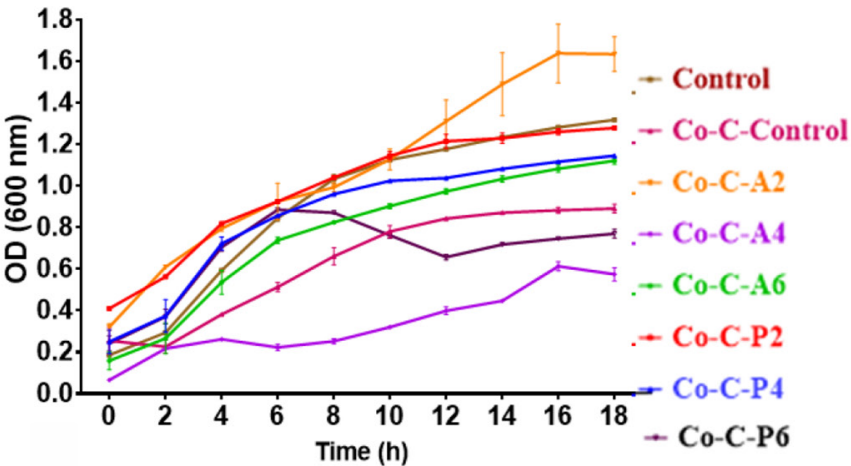

Figure 2. Antifungal activity according to optical density (OD) at $600 \mathrm{~nm}$ of camel whey (A), camel casein (B), cow whey (C), and cow casein (D) hydrolysates $\left(1.5 \mathrm{mg}\right.$ protein equivalent) against Candida albicans $\left(1 \times 10^{4} \mathrm{cfu} / \mathrm{mL}\right)$ at $37^{\circ} \mathrm{C}$ for $18 \mathrm{~h}$. Data represent mean $\pm \mathrm{SD}(\mathrm{n}$ = 3). Control: broth only; Ca-C: camel casein; Ca-W: camel whey; Co-C: cow casein; Co-W: cow whey; A2, A4, and A6 refer to alcalase-derived hydrolysates; P2, P4, and P6 refer to protease-derived hydrolysates at 2, 4, and 6 h of hydrolysis. 
A

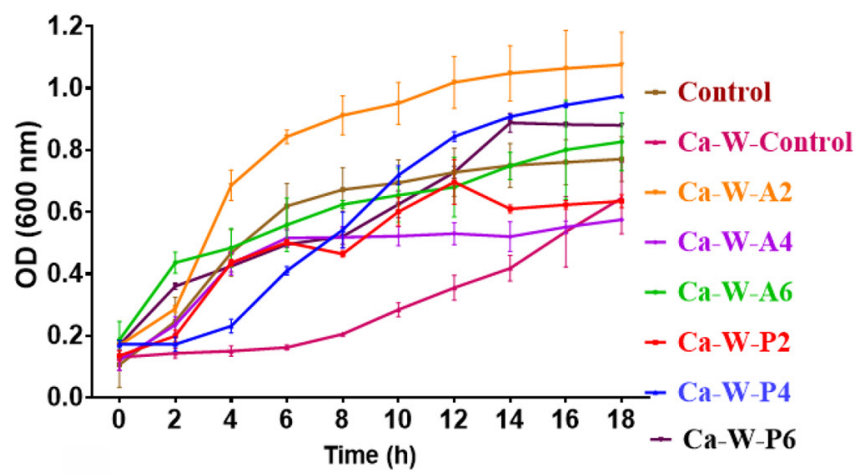

C

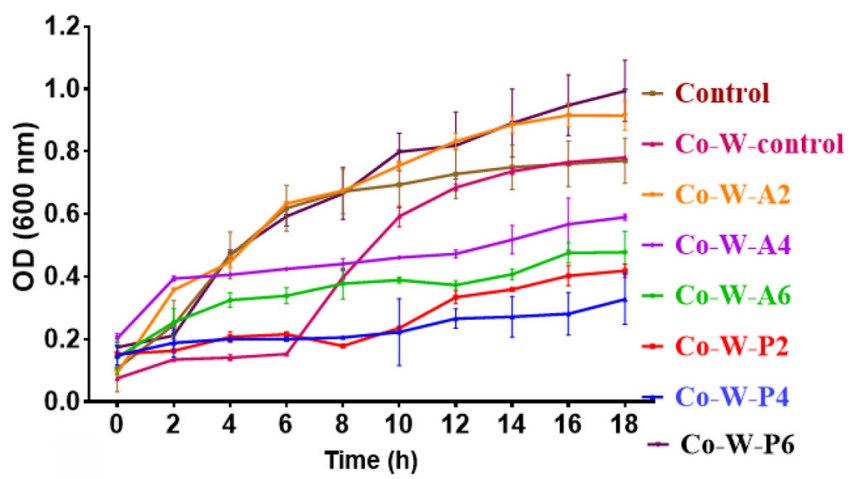

B Camel Casein (CaC)

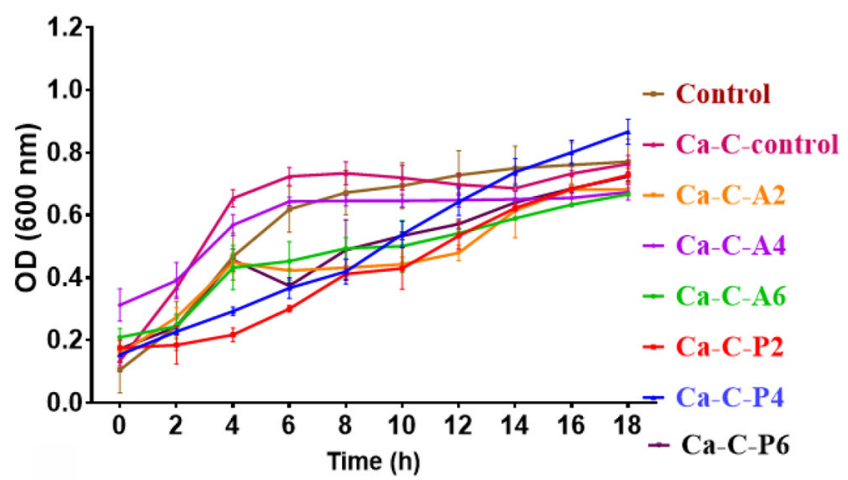

D Cow Casein (CoC)

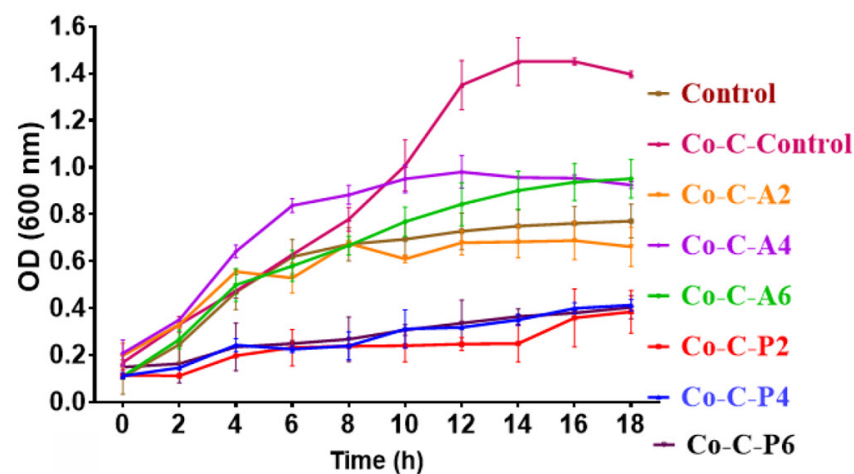

Figure 3. Antifungal activity according to optical density at $600 \mathrm{~nm}$ of camel whey (A), camel casein (B), cow whey (C), and cow casein (D) hydrolysates $\left(1.5 \mathrm{mg}\right.$ protein equivalent) against Candida krusei $\left(1 \times 10^{4} \mathrm{cfu} / \mathrm{mL}\right)$ at $37^{\circ} \mathrm{C}$ for $18 \mathrm{~h}$. Data represent mean $\pm \mathrm{SD}(\mathrm{n}=3)$. Control: broth only; Ca-C: camel casein; Ca-W: camel whey; Co-C: cow casein; Co-W: cow whey; A2, A4, and A6 refer to alcalase-derived hydrolysates; $\mathrm{P} 2, \mathrm{P} 4$, and $\mathrm{P} 6$ refer to protease-derived hydrolysates at 2, 4, and $6 \mathrm{~h}$ of hydrolysis.

Ca-C-A4) demonstrated the highest antifungal activity after $18 \mathrm{~h}$ against $C$. parapsilopsis, followed by protease-2 $\mathrm{h}$ derived camel whey hydrolysate (Ca-W-P2) and alcalase-2 $\mathrm{h}$ derived camel casein hydrolysate $\mathrm{Ca}-\mathrm{C}-\mathrm{A} 2$ (Figure 4A and $\mathrm{C}$ ).

The possible reason for higher antifungal activity among camel milk hydrolysates in comparison to cow milk hydrolysates could be the differences in the composition and content of different proteins between cow and camel milk and in turn the amino acid sequences of the peptides generated upon hydrolysis. Scientifically, it is well known that camel milk is richer in antimicrobial proteins and peptides generated thereof when compared with cow milk (i.e., lactoferrin, immunoglobulins, and so on are present in higher concentration in camel milk; Khalesi et al., 2017). More studies in this direction to elucidate the exact mechanism and reason of these antifungal activity are needed. Additionally, the variation seen between the inhibition of various Candida species could also be attributed to the genetic dissimilarities between the different fungal strains used. Whereas $C$. albicans and C. parapsilopsis belong to a clade whose members translate the CTG codon as serine instead of leucine, C. krusei is a different clade member having multiple drug resistance properties (Diezmann et al., 2004).

\section{Inhibition Activity of Selected Hydrolysates Against Various Candida Species Through Cell Viability Methods}

The hydrolysates that showed potent anti-Candida effects specially against fluconazole-resistant $C$. krusei and $C$. parapsilopsis in the preliminary screening assay using the OD method were further selected and tested for their effect on the log cfu count of antifungal activity against C. albicans, C. krusei, and C.parapsilopsis and the results were present as $\%$ inhibition. Two intact proteins $\mathrm{Co}-\mathrm{W}$ and $\mathrm{Co}-\mathrm{C}$ were also selected as a negative control for further experimentation.

The 4 hydrolysates (Co-W-A6, Co-C-P6, Ca-C-A2, Ca-C-A4) that have shown an overall better antifungal 
activity and a commercial antifungal drug (fluconazole) as a positive control were examined and the percentage of inhibition against all 3 Candida species was determined. Significant $(P<0.05)$ differences between the antifungal activities of cow and camel casein and whey hydrolysates against $C$. albicans growth inhibition were noticed (Figure 5A). The camel casein hydrolysates generated with alcalase-2 h (Ca-C-A2) displayed a higher percentage of inhibition against $C$. albicans $(93.69 \pm 0.26 \%)$ followed by the cow casein generated by protease- $6 \mathrm{~h}$ (Co-C-P $6 ; 81.66 \pm 0.99 \% ; P<0.05)$. Based on the percentage of inhibition, alcalase- and protease-derived casein hydrolysates were even higher than that of fluconazole, a conventional antifungal agent $(76.92 \pm 4.72 \%)$, confirming the high anti-C. albicans activity of camel (Ca-C-A2) and cow (Co-C-P6) casein hydrolysate. On the contrary, unhydrolyzed cow casein and whey proteins did not show any antifungal activity toward C. albicans.

The profile of the antifungal activity was, however, different in the case of C. krusei (Figure 5B). All of the 4 selected hydrolysates showed significant growth inhibition against $C$. krusei. The highest inhibition was displayed by alcalase- 4 h-generated camel casein hydrolysate (Ca-C-A $4 ; 57.11 \pm 0.72 \%$ ) followed by alcalase- 2 h-generated camel casein hydrolysate (Ca-C-A4; 41.84 $\pm 1.11 \% ; P<0.05)$. Hydrolysates derived from the cow casein protease-6 $\mathrm{h}$ (Co-C-P6) and whey alcalase- $6 \mathrm{~h}$ (Co-W-A6) also exhibited anti-C. krusei activity, but the efficiency of inhibition was less compared with camel casein protein hydrolysates $(P<0.05)$. Interestingly, the control cow casein proteins showed antifungal activity $(15.8 \pm 1.22 \%)$ against $C$. krusei, which was similar to protease- $6 \mathrm{~h}$ cow casein-derived hydrolysate (Co-C-P6) and fluconazole $(P>0.05)$. Overall, the camel casein A4 (Ca-C-A4) hydrolysate inhibited the growth of $C$. krusei much higher compared with the fluconazole. On the other hand, cow whey proteins did not exhibit any anti-C. krusei activity.

Next, we determined the antifungal activity of cowand camel milk-derived hydrolysates against $C$. parapsilopsis (Figure 5C). The anti-C. parapsilopsis activity profile of our hydrolysates was much different compared with the other 2 Candida species. Unhydrolyzed cow
A

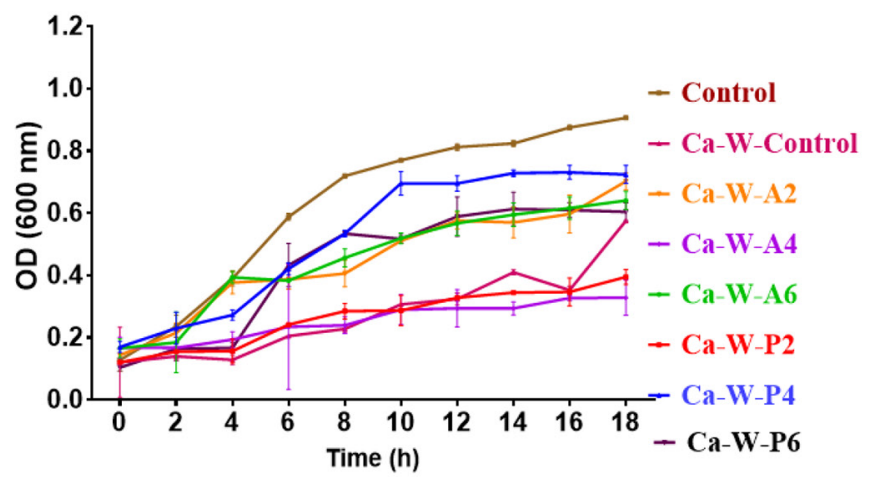

C

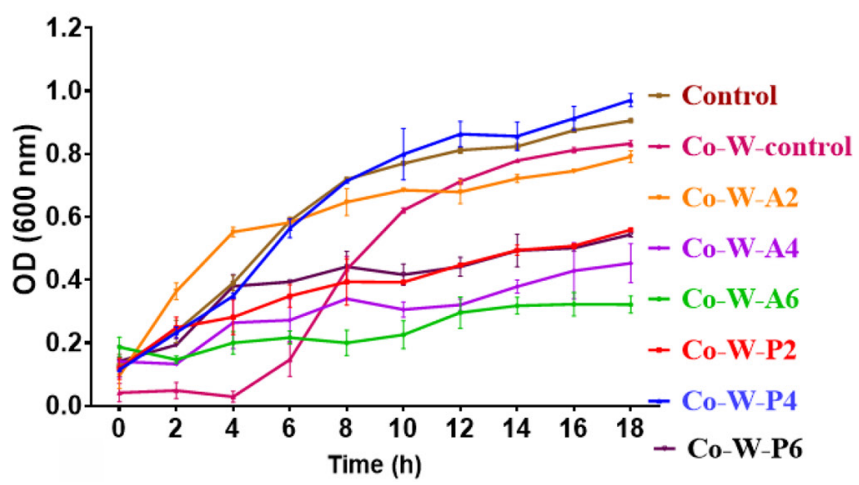

B Camel casein (CaC)

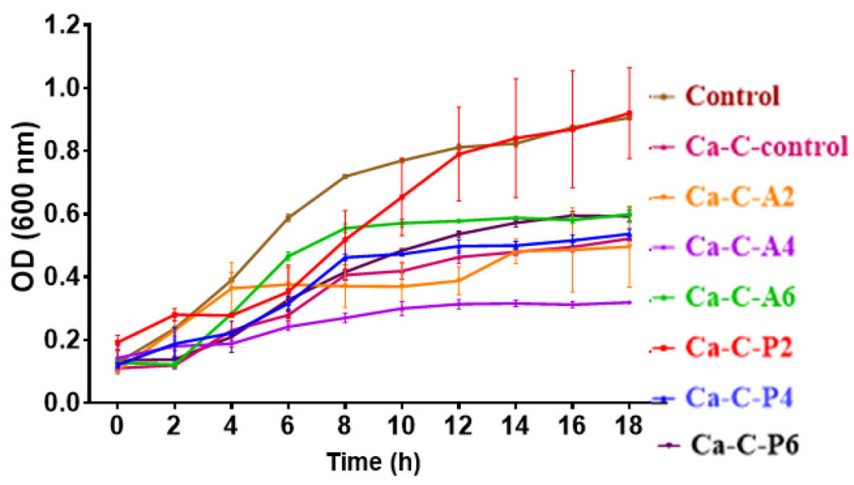

D Cow Casein (CoC)

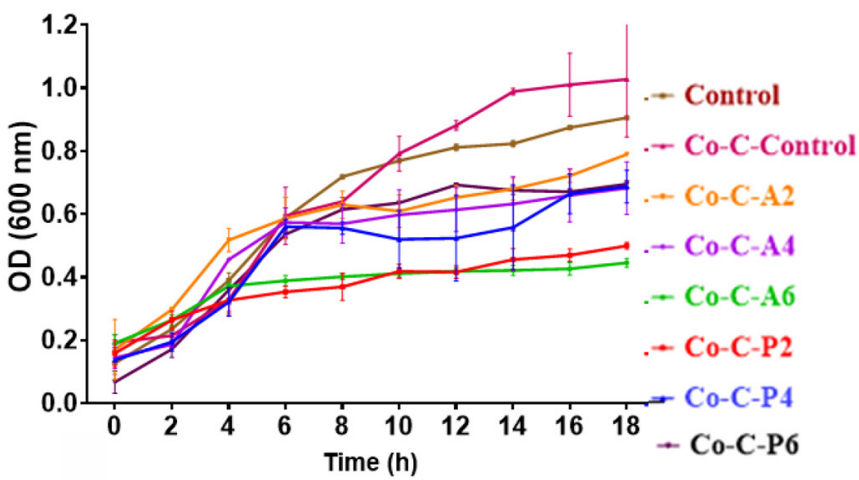

Figure 4. Antifungal activity according to optical density (OD) at $600 \mathrm{~nm}$ of camel whey (A), camel casein (B), cow whey (C), and cow casein (D) hydrolysates $\left(1.5 \mathrm{mg}\right.$ protein equivalent) against Candida parapsilopsis $\left(1 \times 10^{4} \mathrm{cfu} / \mathrm{mL}\right)$ at $37^{\circ} \mathrm{C}$ for $18 \mathrm{~h}$. Data represent mean \pm $\mathrm{SD}(\mathrm{n}=3)$. Control: broth only; Ca-C: camel casein; Ca-W: camel whey; Co-C: cow casein; Co-W: cow whey; A2, A4, and A6 refer to alcalasederived hydrolysates; P2, P4, and P6 refer to protease-derived hydrolysates at 2, 4, and 6 h of hydrolysis. 
casein and whey proteins did not display any inhibition against C. parapsilopsis. Only 2 hydrolysates showed inhibition potential: Co-C-P6 $(23.82 \pm 4.14 \%)$ was the highest followed by Ca-C-A4 (19.31 $\pm 0.84 \%)$, and much lower than that of fluconazole $(29.86 \pm 1.11 \%)$. While comparing the antifungal activity of the selected hydrolysates (Co-W-A6, Co-C-P6, Ca-C-A2, Ca-C-A4) against C. albicans, C. krusei, and C. parapsilopsis, all of the 4 hydrolysates exhibited greater inhibitory activity against $C$. albicans. The inhibition demonstrated by Ca-C-A2 (93\%) was significantly higher than that of fluconazole. Ca-C-A4, however, only exhibited moderate inhibition activity $(57 \%)$ against $C$. krusei, but was still higher than fluconazole and other hydrolysates $(P$ $<0.05)$. Among all of the hydrolysates tested for their antifungal activity against $C$. parapsilopsis, only Ca-CA4 and Co-C-P6 showed inhibition activity against it. In addition, the current study reveals that hydrolysates of camel and cow milk casein have the pronounced capacity to inhibit the growth of various Candida species when compared with unhydrolyzed control samples and in some occasions more powerful than the known antifungal agent, fluconazole, pointing toward a powerful therapeutic alternative to antibiotics.

Several studies have explored the antibacterial activity of cow and camel milk protein hydrolysates; however, few studies have considered the antifungal activity of those hydrolysates. This is the first study that highlights the antifungal property of camel milk protein hydrolysates. Previous reports have suggested that apo-lactoferrin and lactoferrin could reduce the growth of several Candida clinical isolates and suggested synergism of lactoferrin with conventional antifungals would have therapeutic potential (Kuipers et al., 1999). Similarly, HLopt2 (altered sequence CFQWKRAMRKVR) was examined for antifungal activity and was shown to have effective fungicidal activity toward Candida neoformans, C. albicans, C. parapsilosis, Candida kefir, and C. krusei, both in in vitro and in vivo studies (Kondori et al., 2011). The antifungal activity reported was linked to the irregular changes in the cell wall that lead to separation of cytoplasmic and mitochondrial membranes in the fungal cells, thus leading to their inhibition (Kondori et al., 2011). Future work should be guided toward analyzing the presence of bioactive peptide (HLopt2) in camel- and cow protein-derived hydrolysates and its concentration should also be determined.

Previous researchers have suggested that antifungal effects of peptides are quite conserved or narrow. Differences in amino acid composition and their sequence contribute to the variation of their bioactive properties such as antibacterial or antifungal activities (Nakano et al., 2019). The primary mechanism of antifungal action of peptides is driven through membrane destabilization, whereas immunomodulation and iron sequestration play secondary roles (Fernandes and Carter, 2017). Additionally, dissipation of the proton gradient across the cell membrane and aggregation of cytoplasmic materials through stimulation of ATP synthesis and extracellular secretion, causing pore formation in the plasma membrane, are also reported as possible
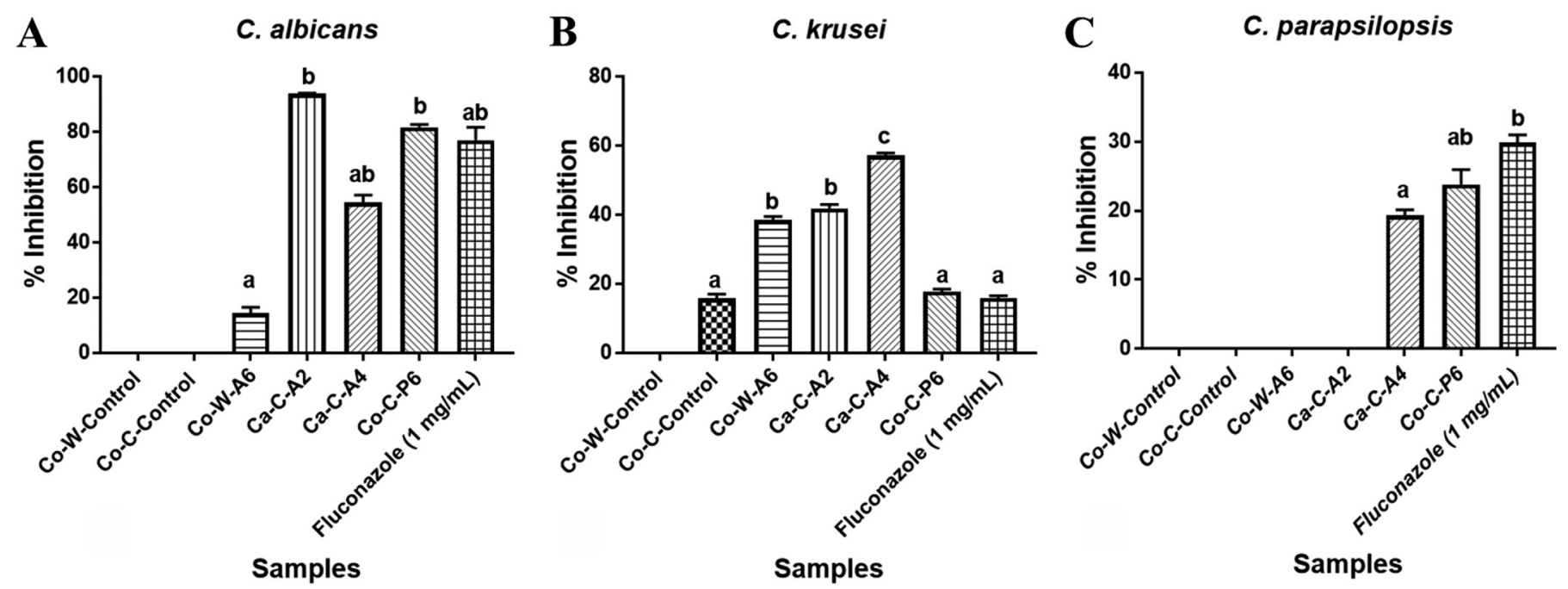

Figure 5. Percentage inhibition of selected camel and cow milk casein- and whey-derived protein hydrolysates $(30 \mathrm{mg} / \mathrm{mL}$ protein equivalent) against Candida albicans (A), Candida krusei (B), and Candida parapsilosis (C). Co-W-Control: cow whey unhydrolyzed; Co-C-Control: cow casein unhydrolyzed; Co-W-A6: alcalase-generated cow whey hydrolysate after 6 h; Ca-C-A2 and Ca-C-A4: alcalase-generated camel casein hydrolysates after 2 and $4 \mathrm{~h}$; Co-C-P6: protease-generated cow casein hydrolysate after $6 \mathrm{~h}$; fluconazole: commercial antifungal drug (1 mg/mL). All values are expressed as mean $\pm \mathrm{SD}(\mathrm{n}=3)$. Different letters indicate a significant variation among various treatments $(P<0.05)$. 
antifungal mechanisms of bioactive peptides (Ueta et al., 2001; Gifford et al., 2005). In the present study we also believe that peptides obtained from camel and cow proteins could use different mechanisms for their antifungal effect; however, considerable research is still required to understand the antifungal actions of these molecules.

\section{CONCLUSIONS}

The results of this study demonstrated that the antifungal potential of cow and camel milk proteins was enhanced upon their hydrolysis, confirming the production of some potent AMP. Candida parapsilosis was found to be the most resistant species toward the protein hydrolysates generated from cow and camel milk proteins. The present study confirmed and extended the knowledge regarding the antifungal activity of cow and camel milk protein hydrolysates. Future research should be directed to dose-specific responses of protein hydrolysates against different Candida species, as well as studies on the fractionation and identification of the peptides in potential hydrolysates. Overall, camel milk protein hydrolysates should be studied further and might be used as future therapeutics for Candida infections via topical applications of these hydrolysates using a cream-based formula.

\section{ACKNOWLEDGMENTS}

The authors are grateful to United Arab Emirates University for funding this research through a research grant (UPAR-31F094) awarded to the principal investigator, Sajid Maqsood. The authors have not stated any conflicts of interest.

\section{REFERENCES}

Abdalla, E. B., A. E.-H. Anis Ashmawy, M. H. Farouk, O. Abd ElRahman Salama, F. A. Khalil, and A. F. Seioudy. 2015. Milk production potential in Maghrebi she-camels. Small Rumin. Res. 123:129-135. https://doi.org/10.1016/j.smallrumres.2014.11.004.

Abderrahmane, F., F. Mezmaze, A. Chekroun, D. Saidi, and O. Kheroua. 2015. In vitro digestibility of the dromedary whey proteins: Potential uses in infant milk allergies. Int. J. Pharm. Pharm. Sci. 7:e120.

Ahamad, S. R., M. Raish, A. Ahmad, and F. Shakeel. 2017. Potential health benefits and metabolomics of camel milk by GC-MS and ICP-MS. Biol. Trace Elem. Res. 175:322-330. https://doi.org/10 .1007/s12011-016-0771-7.

Al-Shamsi, K. A., P. Mudgil, H. M. Hassan, and S. Maqsood. 2018. Camel milk protein hydrolysates with improved technofunctional properties and enhanced antioxidant potential in in vitro and in food model systems. J. Dairy Sci. 101:47-60. https://doi.org/10 $.3168 /$ jds.2017-13194.

Alavi, F., M. Salami, Z. Emam-Djomeh, and M. Mohammadian. 2017. Nutraceutical Properties of Camel Milk. Elsevier.

Algboory, H. L., A. K. Al-Darwash, E. M. Jarallah, and B. J. Muhialdin. 2017. Partial purification of antimicrobial peptides from fermented Iraqi camel's milk by Streptococcus thermophilus and Lactobacillus delbrueckii sp. Bulgaricus. Biochem. Cell. Arch. 17:697-701.

Baba, W., P. Mudgil, H. Kamal, B. Kilari, C. Y. Gan, and S. Maqsood. 2021. Identification and characterization of novel $\alpha$-amylase and $\alpha$-glucosidase inhibitory peptides from camel whey proteins. J. Dairy Sci. 104:1364-1377. https://doi.org/10.3168/jds.2020-19271.

Bahari, A. N., N. Saari, N. Salim, and S. E. Ashari. 2020. Response factorial design analysis on papain-generated hydrolysates from Actinopyga lecanora for determination of antioxidant and antityrosinase activities. Molecules 25:2663. https://doi.org/10.3390/ molecules25112663.

Bao, Z., Y. Zhao, X. Wang, and Y.-J. Chi. 2017. Effects of degree of hydrolysis $(\mathrm{DH})$ on the functional properties of egg yolk hydrolysate with alcalase. J. Food Sci. Technol. 54:669-678. https://doi .org/10.1007/s13197-017-2504-0.

Chen, C. H., and T. K. Lu. 2020. Development and challenges of antimicrobial peptides for therapeutic applications. Antibiotics (Basel) 9:24. https://doi.org/10.3390/antibiotics9010024.

Dadar, M., R. Tiwari, K. Karthik, S. Chakraborty, Y. Shahali, and K. Dhama. 2018. Candida albicans - Biology, molecular characterization, pathogenicity, and advances in diagnosis and control - An update. Microb. Pathog. 117:128-138. https://doi.org/10.1016/j .micpath.2018.02.028.

de Oliveira Santos, G. C., C. C. Vasconcelos, A. J. O. Lopes, M. S. de Sousa Cartágenes, A. K. D. B. Filho, F. R. F. do Nascimento, R. M. Ramos, E. R. R. B. Pires, M. S. de Andrade, F. M. G. Rocha, and C. de Andrade Monteiro. 2018. Candida infections and therapeutic strategies: Mechanisms of action for traditional and alternative agents. Front. Microbiol. 9:1351. https://doi.org/ 10.3389/fmicb.2018.01351.

Diezmann, S., J. Cox Cymon, G. Schönian, J. Vilgalys Rytas, and G. Mitchell Thomas. 2004. Phylogeny and evolution of medical species of Candida and related taxa: A multigenic analysis. J. Clin. Microbiol. 42:5624-5635.

El-Agamy, E. I. 2009. Bioactive components in camel milk. Pages 159194 in Bioactive Components in Milk and Dairy Products. Vol. 107. Y. W. Park, ed. Wiley-Blackwell.

Esmaeilpour, M., M. R. Ehsani, M. Aminlari, S. Shekarforoush, and E. Hoseini. 2016. Antimicrobial activity of peptides derived from enzymatic hydrolysis of goat milk caseins. Comp. Clin. Pathol. 25:599-605. https://doi.org/10.1007/s00580-016-2237-x.

Farag, S., and K. Kebary. 1992. Chemical composition and physical properties of camel's milk and milk fat. Pages 57-67 in Proc. 5th Egyptian Conference for Dairy Science and Technology.

Fernandes, K. E., and D. A. Carter. 2017. The antifungal activity of lactoferrin and its derived peptides: Mechanisms of action and synergy with drugs against fungal pathogens. Front. Microbiol. 8:2. https://doi.org/10.3389/fmicb.2017.00002.

Gifford, J. L., H. N. Hunter, and H. Vogel. 2005. Lactoferricin. Cell. Mol. Life Sci. 62:2588-2598. https://doi.org/10.1007/s00018-005 $-5373-\mathrm{z}$.

Ishak, N. H., and N. M. Sarbon. 2018. A review of protein hydrolysates and bioactive peptides deriving from wastes generated by fish processing. Food Bioprocess Technol. 11:2-16. https://doi.org/10 .1007/s11947-017-1940-1.

Jamiu, A. T., J. Albertyn, O. M. Sebolai, and C. H. Pohl. 2021. Update on Candida krusei, a potential multidrug-resistant pathogen. Med. Mycol. 59:14-30. https://doi.org/10.1093/mmy/myaa031.

Jung, T.-H., S.-S. Yun, W.-J. Lee, J.-W. Kim, H.-K. Ha, M. Yoo, H.-J. Hwang, W.-M. Jeon, and K.-S. Han. 2016. Hydrolysis by alcalase improves hypoallergenic properties of goat milk protein. Korean J. Food Sci. Anim. Resour. 36:516-522. https://doi.org/10.5851/ kosfa.2016.36.4.516.

Kamal, H., P. Mudgil, B. Bhaskar, A. F. Fisayo, C.-Y. Gan, and S. Maqsood. 2021. Amaranth proteins as potential source of bioactive peptides with enhanced inhibition of enzymatic markers linked with hypertension and diabetes. J. Cereal Sci. 101:103308. https:/ /doi.org/10.1016/j.jcs.2021.103308.

Khalesi, M., M. Salami, M. Moslehishad, J. Winterburn, and A. A. Moosavi-Movahedi. 2017. Biomolecular content of camel milk: A 
traditional superfood towards future healthcare industry. Trends Food Sci. Technol. 62:49-58. https://doi.org/10.1016/j.tifs.2017.02 .004 .

Khaskheli, M., M. Arain, S. Chaudhry, A. Soomro, and T. Qureshi. 2005. Physico-chemical quality of camel milk. J. Agric. Soc. Sci. $2: 164-166$.

Kondori, N., L. Baltzer, G. T. Dolphin, and I. Mattsby-Baltzer. 2011. Fungicidal activity of human lactoferrin-derived peptides based on the antimicrobial $\alpha \beta$ region. Int. J. Antimicrob. Agents 37:51-57. https://doi.org/10.1016/j.ijantimicag.2010.08.020.

Konuspayeva, G., B. Faye, G. Loiseau, and D. Levieux. 2007. Lactoferrin and immunoglobulin contents in camel's milk (Camelus bactrianus, Camelus dromedarius, and hybrids) from Kazakhstan. J. Dairy Sci. 90:38-46. https://doi.org/10.3168/jds.S0022 -0302(07)72606-1.

Kuipers, M. E., H. G. de Vries, M. C. Eikelboom, D. K. F. Meijer, and P. J. Swart. 1999. Synergistic fungistatic effects of lactoferrin in combination with antifungal drugs against clinical Candida isolates. Antimicrob. Agents Chemother. 43:2635-2641. https://doi .org/10.1128/AAC.43.11.2635.

Kumar, D., M. K. Chatli, R. Singh, N. Mehta, and P. Kumar. 2016a. Antioxidant and antimicrobial activity of camel milk casein hydrolysates and its fractions. Small Rumin. Res. 139:20-25. https://doi .org/10.1016/j.smallrumres.2016.05.002.

Kumar, D., M. K. Chatli, R. Singh, N. Mehta, and P. Kumar. 2016b. Enzymatic hydrolysis of camel milk casein and its antioxidant properties. Dairy Sci. Technol. 96:391-404. https://doi.org/10 $.1007 / \mathrm{s} 13594-015-0275-9$.

Li, L., J. Sun, S. Xia, X. Tian, M. J. Cheserek, and G. Le. 2016. Mechanism of antifungal activity of antimicrobial peptide APP, a cell-penetrating peptide derivative, against Candida albicans: intracellular DNA binding and cell cycle arrest. Appl. Microbiol. Biotechnol. 100:3245-3253. https://doi.org/10.1007/s00253-015 $-7265-y$.

Mayer, F. L., D. Wilson, and B. Hube. 2013. Candida albicans pathogenicity mechanisms. Virulence 4:119-128. https://doi.org/10 $.4161 /$ viru. 22913.

Mehaia, M. A., M. A. Hablas, K. M. Abdel-Rahman, and S. A. ElMougy. 1995. Milk composition of majaheim, wadah and hamra camels in Saudi Arabia. Food Chem. 52:115-122. https://doi.org/ 10.1016/0308-8146(94)P4189-M.

Mohanty, D., R. Jena, P. K. Choudhury, R. Pattnaik, S. Mohapatra, and M. R. Saini. 2016. Milk derived antimicrobial bioactive peptides: A review. Int. J. Food Prop. 19:837-846. https://doi.org/10 $.1080 / 10942912.2015 .1048356$.

Mudgil, P., W. N. Baba, H. Kamal, R. J. FitzGerald, H. M. Hassan, M. A. Ayoub, C.-Y. Gan, and S. Maqsood. 2022. A comparative investigation into novel cholesterol esterase and pancreatic lipase inhibitory peptides from cow and camel casein hydrolysates generated upon enzymatic hydrolysis and in vitro digestion. Food Chem. 367:130661. https://doi.org/10.1016/j.foodchem.2021.130661.

Mudgil, P., B. Baby, Y.-Y. Ngoh, R. Vijayan, C.-Y. Gan, and S. Maqsood. 2019. Identification and molecular docking study of novel cholesterol esterase inhibitory peptides from camel milk proteins. J. Dairy Sci. 102:10748-10759. https://doi.org/10.3168/jds.2019 $-16520$.

Mudgil, P., H. Kamal, B. Priya Kilari, M. A. S. Mohd Salim, C.-Y. Gan, and S. Maqsood. 2021. Simulated gastrointestinal digestion of camel and bovine casein hydrolysates: Identification and characterization of novel anti-diabetic bioactive peptides. Food Chem. 353:129374. https://doi.org/10.1016/j.foodchem.2021.129374.

Mudgil, P., B. P. Kilari, H. Kamal, O. A. Olalere, R. J. FitzGerald, C.-Y. Gan, and S. Maqsood. 2020. Multifunctional bioactive peptides derived from quinoa protein hydrolysates: Inhibition of $\alpha$-glucosidase, dipeptidyl peptidase-IV and angiotensin I converting enzymes. J. Cereal Sci. 96:103130. https://doi.org/10.1016/j .jcs.2020.103130.
Nakano, M., M. Suzuki, H. Wakabayashi, K. Hayama, K. Yamauchi, F. Abe, and S. Abe. 2019. Synergistic anti-candida activities of lactoferrin and the lactoperoxidase system. Drug Discov. Ther. 13:28-33. https://doi.org/10.5582/ddt.2019.01010.

Nielsen, P. M., D. Petersen, and C. Dambmann. 2001. Improved method for determining food protein degree of hydrolysis. J. Food Sci. 66:642-646. https://doi.org/10.1111/j.1365-2621.2001.tb04614.x.

Nobile, C. J., and A. D. Johnson. 2015. Candida albicans biofilms and human disease. Annu. Rev. Microbiol. 69:71-92. https://doi.org/ 10.1146/annurev-micro-091014-104330.

Omar, A., N. Harbourne, and M. J. Oruna-Concha. 2016. Quantification of major camel milk proteins by capillary electrophoresis. Int. Dairy J. 58:31-35. https://doi.org/10.1016/j.idairyj.2016.01.015.

Osman, A., H. A. Goda, M. Abdel-Hamid, S. M. Badran, and J. Otte. 2016. Antibacterial peptides generated by Alcalase hydrolysis of goat whey. Lebensm. Wiss. Technol. 65:480-486. https://doi.org/ 10.1016/j.lwt.2015.08.043

Rossignol, T., B. Kelly, C. Dobson, and C. d'Enfert. 2011. Endocytosis-mediated vacuolar accumulation of the human ApoE apolipoprotein-derived ApoEdpL-W antimicrobial peptide contributes to its antifungal activity in Candida albicans. Antimicrob. Agents Chemother. 55:4670-4681. https://doi.org/10.1128/AAC.00319 -11 .

Salami, M., R. Yousefi, M. R. Ehsani, S. H. Razavi, J.-M. Chobert, T. Haertlé, A. A. Saboury, M. S. Atri, A. Niasari-Naslaji, F. Ahmad, and A. A. Moosavi-Movahedi. 2009. Enzymatic digestion and antioxidant activity of the native and molten globule states of camel $\alpha$-lactalbumin: Possible significance for use in infant formula. Int. Dairy J. 19:518-523. https://doi.org/10.1016/j.idairyj 2009.02.007.

Sbroggio, M. F., M. S. Montilha, V. R. G. de Figueiredo, S. R. Georgetti, and L. E. Kurozawa. 2016. Influence of the degree of hydrolysis and type of enzyme on antioxidant activity of okara protein hydrolysates. Food Sci. Technol. (Campinas) 36:375-381. https://doi.org/10.1590/1678-457X.000216.

Shahi, Z., S. Z. Sayyed-Alangi, and L. Najafian. 2020. Effects of enzyme type and process time on hydrolysis degree, electrophoresis bands and antioxidant properties of hydrolyzed proteins derived from defatted Bunium persicum Bioss. press cake. Heliyon 6:e03365. https://doi.org/10.1016/j.heliyon.2020.e03365.

Shu, G., J. Huang, C. Bao, J. Meng, H. Chen, and J. Cao. 2018. Effect of different proteases on the degree of hydrolysis and angiotensin I-converting enzyme-inhibitory activity in goat and cow milk. Biomolecules 8:101. https://doi.org/10.3390/biom8040101.

Spungin, A., and S. Blumberg. 1989. Streptomyces griseus aminopeptidase is a calcium-activated zinc metalloprotein. Eur. J. Biochem. 183:471-477. https://doi.org/10.1111/j.1432-1033.1989.tb14952.x.

Swelum, A. A., M. T. El-Saadony, M. Abdo, R. A. Ombarak, E. O. Hussein, G. Suliman, A. R. Alhimaidi, A. A. Ammari, H. BaAwadh, A. E. Taha, K. A. El-Tarabily, and M. E. Abd El-Hack. 2021. Nutritional, antimicrobial and medicinal properties of camel's milk: A review. Saudi J. Biol. Sci. 28:3126-3136. https://doi .org/10.1016/j.sjbs.2021.02.057.

Tagliazucchi, D., S. Martini, S. Shamsia, A. Helal, and A. Conte. 2018 Biological activities and peptidomic profile of in vitro-digested cow, camel, goat and sheep milk. Int. Dairy J. 81:19-27. https:// doi.org/10.1016/j.idairyj.2018.01.014.

Trofa, D., A. Gácser, and J. D. Nosanchuk. 2008. Candida parapsilosis, an emerging fungal pathogen. Clin. Microbiol. Rev. 21:606-625. https://doi.org/10.1128/CMR.00013-08.

Turner, S. A., and G. Butler. 2014. The Candida pathogenic species complex. Cold Spring Harb. Perspect. Med. 4:a019778. https://doi .org/10.1101/cshperspect.a019778.

Ueta, E., T. Tanida, and T. Osaki. 2001. A novel bovine lactoferrin peptide, FKCRRWQWRM, suppresses Candida cell growth and activates neutrophils. J. Pept. Res. 57:240-249. https://doi.org/10 .1111/j.1399-3011.2001.00821.x. 